\title{
Microenvironmental Influences and Antigenic Stimulation in Chronic Lymphocytic Leukemia
}

\author{
Till Seiler Wolfgang Hiddemann
}

Medizinische Klinik und Poliklinik III, Klinikum der Universität München-Großhadern, Germany

Formerly described as a homogeneous disease with relentlessly accumulating tumor cells due to resistance to apoptosis, the biological background of chronic lymphocytic leukemia (CLL) is seen more differentiated nowadays. Biological characteristics of the tumor cells not only allow estimating the patient's individual prognosis but also help to decipher the pathomechanisms of the disease.

Cytogenetic aberrations can be detected in up to $80 \%$ of patients [1]. A frequently detected chromosomal aberration is a deletion on the long arm of chromosome 13 that affects the microRNA gene cluster mir-15a and mir-16-1 located in this region [2]. As an early event in the pathogenesis of the disease, the down-regulation or deletion of this cluster is discussed. Intriguingly, it has been experimentally shown that the expression of these microRNAs inversely correlates with bcl-2 expression, an anti-apoptotic protein overexpressed in CLL [2].

Although genetic lesions are important in predisposing leukemic B lymphocytes to prolonged survival and persistence in vivo, CLL blood cells typically undergo apoptosis when cultured in vitro, indicating that the in vivo accumulation of leukemic lymphocytes is also favored by other factors probably originating from the microenvironment. In addition, in vivo kinetic analyses and numerous experimental data such as investigations on telomerase activity and telomere length as well as CD38 expression analyses revealed that CLL is not only a disease of accumulation but a dynamic process with an appreciable level of cell turnover [3-6]. Proliferative events seem to occur in tissues where leukemic cells are able to exploit microenvironment interactions in order to avoid apoptosis and acquire better growth conditions [7].

Next to provision of cytokines and direct cellular interaction, a key element among stimulating microenvironmental factors seems to be signaling through the clone specific B-cell receptor (BCR), a mechanism that has been investigated for several reasons: CLL cells have the phenotypic profile of antigen experienced $\mathrm{B}$ cells $[8,9]$. These experimental observations are corroborated by the notion that the expression of ZAP-70, a molecule involved in B-cell receptor (BCR) signaling, is overexpressed in a subset of patients with poor prognosis [10]. In addition, the leukemic B cells of patients with CLL express a restricted immunoglobulin heavy variable (IGHV) gene repertoire. In a study of 916 Mediterranean CLL patients, almost $22 \%$ expressed IGHV genes which belonged to one of 48 different subsets of sequences with stereotyped heavy chain complementarity-determining regions (HCDR3) [11]. To date, over 100 stereotyped receptors are identified [12]. These receptors are characterized by an intrinsic polyreactivity in IGHV unmutated CLL and, to a lesser degree, in IGHV mutated CLL [13]. Recent studies suggest cytoskeletal structures such as nonmuscle myosin heavy chain IIA and vimentin [14], neo-epitopes created by chemical modifications occurring naturally during apoptosis [15] and microbial antigens $[16,17]$ as potential naturally occurring epitopes.

Reactivity of the CLL BCR to prostate tissue was demonstrated in a study utilizing CLL derived IgM molecules. These IgM specifically bound prostate cells and blocked binding of CLL cells to prostate cells [18]. Intriguingly, that particular patient presented with urinary obstructive syndrome and had leukemic prostate infiltration, indicating that tropism to the prostate might be mediated by the CLL BCR. In this issue of ONKOLOGIE, Fehr and colleagues [19] report the presentation and management of two patients with urinary obstructive syndromes caused by an unusual primary manifestation of SLL/ CLL in the prostate. No information is given about the IGHV mutation status, the VDJ composition and the CDR3 of the patients' clone specific BCR. However, giving the importance of BCR signaling in the pathogenesis of the disease, the idea of a prostate specific antigenic repertoire in these patients warrants further investigation.

\begin{tabular}{ll}
\hline KARGER & ๑ 2009 S. Karger GmbH, Freiburg \\
$\begin{array}{l}\text { Fax }+497614520714 \\
\text { Information@Karger.de } \\
\text { www.karger.com }\end{array}$ & $\begin{array}{l}\text { Accessible online at: } \\
\text { www.karger.com/onk }\end{array}$ \\
\end{tabular}


The symptom complex of urinary obstruction in patients with CLL might frequently be misinterpreted. Lymphoid neoplasms of the urinary tract and male genital organs are relatively rare, comprising less than $5 \%$ of all primary extranodal lymphomas. Exemplarily, in a series of 40 patients with various lymphoid neoplasms of the urinary tract, 4 patients had SLL/CLL [20]. Apart from the urinary tract, infiltration of the skin, gastrointestinal tract, breast, heart, and lung [18] have been observed as manifestations for CLL. In the light of a rapidly growing elderly population, clinicians will more frequently be challenged with the coincidental finding of lymphoproliferative diseases or composite tumors in prostate biopsies. Care has to be taken not to overlook rare causes of urinary obstructive syndromes.

\section{Conflict of Interest}

Till Seiler and Wolfgang Hiddemann have no conflicts of interest to declare.

\section{References}

1 Dohner H, Stilgenbauer S, Benner A, Leupolt E, Krober A, Bullinger L, Dohner K, Bentz M, Lichter P: Genomic aberrations and survival in chronic lymphocytic leukemia. N Engl J Med 2000;343: 1910-6.

2 Calin GA, Ferracin M, Cimmino A, Di Leva G, Shimizu M, Wojcik SE, Iorio MV, Visone R, Sever NI, Fabbri M, Iuliano R, Palumbo T, Pichiorri F, Roldo C, Garzon R, Sevignani C, Rassenti L, Alder H, Volinia S, Liu CG, Kipps TJ, Negrini M, Croce CM: A microRNA signature associated with prognosis and progression in chronic lymphocytic leukemia. N Engl J Med 2005;353:1793-801.

3 Damle RN, Temburni S, Calissano C, Yancopoulos S, Banapour T, Sison C, Allen SL, Rai KR, Chiorazzi N: CD38 expression labels an activated subset within chronic lymphocytic leukemia clones enriched in proliferating B cells. Blood 2007;110: $3352-9$.

4 Damle RN, Batliwalla FM, Ghiotto F, Valetto A, Albesiano E, Sison C, Allen SL, Kolitz J, Vinciguerra VP, Kudalkar P, Wasil T, Rai KR, Ferrarini $\mathrm{M}$, Gregersen $\mathrm{PK}$, Chiorazzi N: Telomere length and telomerase activity delineate distinctive replicative features of the B-CLL subgroups defined by immunoglobulin $\mathrm{V}$ gene mutations. Blood 2004;103:375-82.

5 Messmer BT, Messmer D, Allen SL, Kolitz JE, Kudalkar P, Cesar D, Murphy EJ, Koduru P, Ferrarini M, Zupo S, Cutrona G, Damle RN, Wasil T, Rai KR, Hellerstein MK, Chiorazzi N: In vivo measurements document the dynamic cellular kinetics of chronic lymphocytic leukemia B cells. J Clin Invest 2005;115:755-64.

6 Terrin L, Trentin L, Degan M, Corradini I, Bertorelle R, Carli P, Maschio N, Bo MD, Noventa F, Gattei V, Semenzato G, De Rossi A: Telomerase expression in B-cell chronic lymphocytic leukemia predicts survival and delineates subgroups of patients with the same igVH mutation status and different outcome. Leukemia 2007;21:965-72.

7 Ghia P, Chiorazzi N, Stamatopoulos K: Microenvironmental influences in chronic lymphocytic leukaemia: the role of antigen stimulation. J Intern Med 2008;264:549-62.
8 Klein U, Tu Y, Stolovitzky GA, Mattioli M, Cattoretti G, Husson H, Freedman A, Inghirami G, Cro L, Baldini L, Neri A, Califano A, Dalla-Favera $\mathrm{R}$ : Gene expression profiling of B cell chronic lymphocytic leukemia reveals a homogeneous phenotype related to memory B cells. J Exp Med 2001;194: 1625-38.

-9 Rosenwald A, Alizadeh AA, Widhopf G, Simon R, Davis RE, Yu X, Yang L, Pickeral OK, Rassenti LZ, Powell J, Botstein D, Byrd JC, Grever MR, Cheson BD, Chiorazzi N, Wilson WH, Kipps TJ, Brown PO, Staudt LM: Relation of gene expression phenotype to immunoglobulin mutation genotype in B cell chronic lymphocytic leukemia. J Exp Med 2001;194:1639-47.

10 Crespo M, Bosch F, Villamor N, Bellosillo B, Colomer D, Rozman M, Marce S, Lopez-Guillermo A, Campo E, Montserrat E: ZAP-70 expression as a surrogate for immunoglobulin-variable-region mutations in chronic lymphocytic leukemia. N Engl J Med 2003;348:1764-75.

11 Stamatopoulos K, Belessi C, Moreno C, Boudjograh M, Guida G, Smilevska T, Belhoul L, Stella S, Stavroyianni N, Crespo M, Hadzidimitriou A, Sutton L, Bosch F, Laoutaris N, Anagnostopoulos A, Montserrat E, Fassas A, Dighiero G, Caligaris-Cappio F, Merle-Beral H, Ghia P, Davi F: Over $20 \%$ of patients with chronic lymphocytic leukemia carry stereotyped receptors: pathogenetic implications and clinical correlations. Blood 2007;109:259-70.

12 Murray F, Darzentas N, Hadzidimitriou A, Tobin G, Boudjogra M, Scielzo C, Laoutaris N, Karlsson K, Baran-Marzsak F, Tsaftaris A, Moreno C, Anagnostopoulos A, Caligaris-Cappio F, Vaur D, Ouzounis C, Belessi C, Ghia P, Davi F, Rosenquist R, Stamatopoulos K: Stereotyped patterns of somatic hypermutation in subsets of patients with chronic lymphocytic leukemia: implications for the role of antigen selection in leukemogenesis. Blood 2008;111:1524-33.
13 Herve M, Xu K, Ng YS, Wardemann H, Albesiano E, Messmer BT, Chiorazzi N, Meffre E: Unmutated and mutated chronic lymphocytic leukemias derive from self-reactive B cell precursors despite expressing different antibody reactivity. J Clin Invest 2005;115:1636-43.

14 Chu CC, Catera R, Hatzi K, Yan XJ, Zhang L, Wang XB, Fales HM, Allen SL, Kolitz JE, Rai KR, Chiorazzi N: Chronic lymphocytic leukemia antibodies with a common stereotypic rearrangement recognize nonmuscle myosin heavy chain IIA. Blood 2008;112:5122-9.

15 Catera R, Silverman GJ, Hatzi K, Seiler T, Didier S, Zhang L, Herve M, Meffre E, Oscier DG, Vlassara H, Scofield RH, Chen Y, Allen SL, Kolitz J, Rai KR, Chu CC, Chiorazzi N: Chronic lymphocytic leukemia cells recognize conserved epitopes associated with apoptosis and oxidation. Mol Med 2008;14:665-74.

16 Shaw PX, Goodyear CS, Chang MK, Witztum JL, Silverman GJ: The autoreactivity of anti-phosphorylcholine antibodies for atherosclerosis-associated neo-antigens and apoptotic cells. J Immunol 2003;170:6151-7.

17 Hatzi K, Catera R, Ferrarini M, Fischetti V, Herve M, Meffre E, Chu CC, Chiorazzi N: B-cell chronic lymphocytic leukemia (B-CLL) cells express antibodies reactive with antigenic epitopes expressed on the surface of common bacteria. Blood 2006;108:25.

18 Bogdan CA, Alexander AA, Gorny MK, Matute R, Marjanovic N, Zolla-Pazner S, Walden PD, Furneaux HM, Sidhu GS, Jacobson DR: Chronic lymphocytic leukemia with prostate infiltration mediated by specific clonal membrane-bound $\operatorname{IgM}$. Cancer Res 2003;63:2067-71.

19 Fehr M, Templeton A, Cogliatti S, Aebersold F, Egli F, Gillessen S, Cathomas R: Primary manifestation of small lymphocytic lymphoma in the prostate. Onkologie 2009;32: DOI: 10.1159/000232584.

20 Schniederjan SD, Osunkoya AO: Lymphoid neoplasms of the urinary tract and male genital organs: a clinicopathological study of 40 cases. Mod Pathol 2009;22:1057-65. 